\title{
Role of Bat guano in the reduction of industrial waste water hardness
}

\author{
C. M. Bharambe*
}

Department of Zoology, Vidnyan Mahavidyalaya, Malkapur Dist- Buldana (MS), India

*Corresponding author

\section{A B S T R A C T}

\section{Keywords}

Bioremediation,

Waste water,

Hardness

Bat guano

\section{Article Info}

Accepted:

25 December 2015

Available Online:

10 January 2016
Bat guano is an old faecal matter of bat. The sugar factory effluent has the characteristics of hardness due to the presence of $\mathrm{Ca}^{++}$and $\mathrm{Mg}^{++}$. In the present study an attempt has been made to employ the Bat guano to reduce the hardness of the reclaimed water from sugar factory. There was a significant decrease of hardness against controls. There were 10.47, 14.82, 22.63 and $31.88 \%$ reduction at the interval of 10, 20,30, 40 days in the water after application of Bat guano. The results are discussed with hardness pollution reduction. The present investigation indicates that bat guano used for degradation of water pollutants and bioremediation of aquatic ecosystem and also for waste water treatments.

\section{Introduction}

The word guano originated from the Quichua language of the Inca civilization and means "the droppings of bat". The bats forage at night for insects over a particular area, and they return to the old temples during the day to sleep and care for their young. They attach themselves to ceiling, and their excrement accumulates on the floor below. In some situations the guano can reach a depth of feet in many years and appeared as guano-hip, and it has a valuable importance.

One of the most serious universal, international problems facing us today is the removal of harmful compounds from industrial and municipal as well as anthropogenic waste. If it is discharged into lakes and rivers, a process called eutrophication occurs (Prince, 2003).

Environmental contamination whether it is from industrial or municipal or anthropogenic toxic waste that degrades the various environments is a vital concern to the public. Thus it is crucial to develop and implement accurate means to clean and preserve our precious and deteriorating environment. Although there are many techniques in cleaning environmental contaminations, one process has the most potential, namely bioremediation. 
Bioremediation, or commonly referred to as biodegradation, is a process in which microbes such as bacteria, fungi, yeast, or micro algae are involved in degrading toxic wastes (Pace, 1997 and Knezevich, 2006).

A marvelous symbiosis exits between the microorganisms and bat guano. Bacteria in the mammalian intestinal tract aid in the breakdown of food during digestion. These organisms synthesize enzymes capable of degrading a vast array of substances. Innumerable microbes are regularly excreted along with waste products and together with other organisms; they constitute the microbial population of a bat guano deposit (Steele, 1989).

Large populations of bat deposit thousands of kilograms of dropping annually. An ounce of bat guano contains billions of bacteria, and a single guano deposit may contain thousands of bacterial species. Guano being rich in bioremediation microbes cleans up toxic substances, (Barry et al., 1997). At present we do not know these species.

\section{Materials and Methods}

To study the impact of bat guano on sugar factory effluent, $10 \mathrm{mg}$ bat guano was dissolved in $100 \mathrm{ml}$ of sugar factory effluent (10:100 proportions). After addition of bat guano in sugar factory effluent, the samples were kept undisturbed and analysis was carried out for 40 days at an interval of 10 days for the change in its hardness contents. The change in sugar factory effluent was noted after every 10 days upto 40 days hours. The water was analyzed by using standard methods for water analysis suggested by APHA (1998).

\section{Results and Discussion}

When bat guano was dissolved in sugar factory effluent with hardness (47.14), after 10 days the hardness was found to be decreased gradually to (32.11) upto 40 days (Table, 1). The sugar factory effluent was kept undisturbed till 40 days and the hardness was noted after every 10 days upto 40 days. After 40 days the hardness was seen to be remained constant during observations (Table, 1).

Tilak et al. (2005) reported a number of bacterial species associated with the bat guano belonging to genera, Azospirillum, Alcaligens, Arthrobacter, Acinetobacter, Bacillus, Burkholderia, Enterobacter, Erwinia, Flavobacterium, Pseudomonas, Rhizobium and Serratia. The present study also suggested that this bacterium has high bioremediation capacity. Hutchens et al. (2004) had demonstrated aerobic methane oxidizing bacteria, Methylomonas and Methylococcus in bat guano.

The bacterial enzymes capable of degrading a number of substances (Martin, 1991; Dvorak et al., 1992; Edenborn et al., 1992; Bechard et al., 1994; White and Chang, 1996; Frank, 2000; Kaksonen, et al., 2003; Vallero et al., 2003; Boshoff, et al., 2004; Miranda, 2005; Seena, 2005; Tilak et al., 2005).

Murphy (1989) demonstrated a nutritious broth formation when the bat guano was added in water and further he proved that this broth supported the growth of numerous microbes.

Alley and Mary (1996) stated that an ounce of bat guano contains billions of bacteria and thousands of bacterial species and these bacteria are important to bioremediation. Sridhar et al. (2006) and Pawar et al. (2004) examined the fungal fauna of bat guano and used for bioremediation of Lack soil. 
Table.1 Impact of Bat Guano on Sugar Factory Effluent Content at an Interval of 10 Days

\begin{tabular}{|c|c|c|c|c|c|c|}
\hline \multirow{2}{*}{ Ps } & \multirow{2}{*}{ Sg } & \multicolumn{6}{|c|}{ Time (days) and Ca++ content (mg/l) } \\
\cline { 3 - 7 } & & $\mathbf{0}$ & $\mathbf{1 0}$ & $\mathbf{2 0}$ & $\mathbf{3 0}$ & $\mathbf{4 0}$ \\
\hline C & \multirow{2}{*}{ W1 } & 47.14 & 47.14 & 47.14 & 47.14 & 47.14 \\
Hardness & & \pm 1.08 & \pm 1.03 & \pm 1.10 & \pm 1.24 & \pm 1.32 \\
\hline \multirow{2}{*}{ E } & \multirow{2}{*}{ W2 } & 45.20 & 42.20 & 40.15 & 36.47 & 32.11 \\
Hardness & & \pm 1.45 & \pm 1.20 & \pm 1.22 & \pm 1.05 & \pm 1.15 \\
& & $(4.11)$ & $(10.47)$ & $(14.82)$ & $(22.63)$ & $(31.88)$ \\
\hline
\end{tabular}

All values are the mean of five replicates; values in parenthesis indicates \% of reduction; Ps - Parameters; $\mathrm{Sg}-$ Sampling; W1 - Control water from sugar factory; W2 - Water from sugar factory

In conclusion, other than municipalities, various industries disposing off the industrial effluents are the worst polluters of the aquatic resources. It is of utmost importance, hence, to prevent the pollution of aquatic resources by all possible means to control its quality from further deterioration. Applying microorganisms for industrial pollution control is an area of interest all over the world.

In the present investigation is an attempt to study the impact of bat guano with its rich microbial flora on bioremediation of industrial effluents. The results revealed that within a period of 40 days, there was a remarkable reduction in the physicochemical parameters of industrial effluents, thus stabilizing the industrial effluents, suggesting that industrial effluents can be effectively treated by bat guano.

No much work has been carried out on the bat guano in India and hence it was thought to study the impact of bat guano from and to assess the feasibility of the bat guano as supplementary bioremediatant.

\section{References}

APHA, (1998) Standard methods for the examination of water and wastewater, 20th ed. APHA, AWWA and WEF New York, Washington DC.

Chapelle, F.H. Bioremediation: Nature's
Way to a Cleaner Environment. U. S. Geological _ _ Survey. _ URL: http://water.usgs.gov/wid/htmil/ bioremed. html.

Conde-Costas, C (1991) The effect of bat guano on the water quality of the Cueva EL Convento stream in Gauayanilla, Puerto Rico. Nss. Bull. 53(1):15.

Dash, M. C., Mishra P. C., Kar G. K. and Das R. C. (1986) Hydrobiology of Hirakund Dam Reservoir. In: Ecology and pollution of Indian Lakes and Reservoirs. Mishra Publishing House, New Delhi, p. 317-337.

Dilip, K. M. and N. R. Markandey (2002) Microorganisms in Bioremediation/ edited by. New Delhi, Capital Pub., viii, 190 p., tables, figs., ISBN 8185589-08-9.

Edenborn, D.H., R. S. Hedin (1992) Treatment of water by using sulphate reducing bacteria: Biotech. Bioeng. 30:512-516.

Keleher, S. (1996) Guano: Bats' Gifts to Gardeners. 14(1): pp. 15-17.

Knezevich, V.; O. Koren; E. Z. Ron; E. Rosenberg (2006) Petroleum Bioremediation in Seawater Using Guano. Bioremediation Journal, Vol. $10^{\text {th }}$ Issue 3, p83-91, 9p.

Pawar, K. V. and S. S. Deshmukh (2004): Bioremedition of Lack soil using bat guano. Indian J. Environ and Ecoplan. 8(3):699-704. 
Pierce, W. (1999) Speech on "Bat guano" Sept., 1999. Cassette from National Vanguard Books, P.O. Box 330, Hillsboro, WV 24946.

Prince, R. C. (2003) Bioremediation in marine environments. Prince RC. Exxon Research and Engineering, Annandale, NJ 08801. Bioremediation.

Steele, D. B. (1989) Bats, Bacteria and Biotechnology. 7(1):3-4.
Tuttle, M.D. (1986) Endangered gray bats benefits from protection. Bat, Vol. 4(4), 1986.

Vidali, M. (2001) Bioremediation. An overview. Dipartimento di Chimica Inorganica, Metallorganica, e Analitica, Università di Padova Via Loredan, 435128 Padova, Italy. Pure Appl. Chem., Vol. 73, No. 7, pp. 1163-1172, 2001.

\section{How to cite this article:}

Bharambe, C. M., 2016. Role of Bat guano in the reduction of industrial waste water hardness. Int.J.Curr.Microbiol.App.Sci.5(1): 586-589. hittp://dx.doi.org/10.20546/ijcmas.2016.501.060 